\title{
A Novel Environment-Friendly Adhesive Based on Recycling of Broussonetia papyrifera Leaf Forestry Waste Protein
}

\author{
Cheng Li ${ }^{1}$, Yang Tang ${ }^{1}$, Yujie Wang ${ }^{1}$, Xiaoyu Yuan ${ }^{2, *} \mathbb{C}$, Bengang Zhang ${ }^{3, *}$, Zhigang $\mathrm{Wu}^{4, *} \mathbb{D}$ and Huafeng Tian ${ }^{5}$ \\ 1 College of Forestry, Henan Agricultural University, Zhengzhou 450002, China; licheng@henau.edu.cn (C.L.); \\ tangy1125@163.com (Y.T.); wangyujie25141026@163.com (Y.W.) \\ 2 College of Food Science and Technology, Henan Agricultural University, Zhengzhou 450002, China \\ 3 IUT-LERMAB, University of Lorraine, 88000 Epinal, France \\ 4 College of Forestry, Guizhou University, Guiyang 550025, China \\ 5 Beijing Key Laboratory of Quality Evaluation Technology for Hygiene and Safety of Plastics, \\ College of Chemistry and Materials Engineering, Beijing Technology and Business University, \\ Beijing 100048, China; tianhuafeng@th.btbu.edu.cn \\ * Correspondence: yuanxyscience@henau.edu.cn (X.Y.); zbg18082968142@163.com (B.Z.); \\ wzhigang9@163.com (Z.W.)
}

Citation: Li, C.; Tang, Y.; Wang, Y.; Yuan, X.; Zhang, B.; Wu, Z.; Tian, H. A Novel Environment-Friendly Adhesive Based on Recycling of Broussonetia papyrifera Leaf Forestry Waste Protein. Forests 2022, 13, 291. https://doi.org/10.3390/f13020291 Academic Editors: Youming Dong, Yutao Yan and Angela Lo Monaco

Received: 9 December 2021

Accepted: 30 January 2022

Published: 11 February 2022

Publisher's Note: MDPI stays neutral with regard to jurisdictional claims in published maps and institutional affiliations.

Copyright: (C) 2022 by the authors. Licensee MDPI, Basel, Switzerland. This article is an open access article distributed under the terms and conditions of the Creative Commons Attribution (CC BY) license (https:// creativecommons.org/licenses/by/ $4.0 /)$.

\begin{abstract}
Wood adhesive was prepared using Broussonetia papyrifera waste leaf protein as the raw material. The performance of the B. papyrifera leaf protein adhesive compared to soy protein was investigated using X-ray diffraction, Fourier transform infrared spectroscopy, and differential scanning calorimetry. The results indicated that both B. papyrifera leaf protein and soy protein were spherical proteins that could easily form three-dimensional crosslinked network structures and were of potential for protein adhesive preparation. The B. papyrifera leaf and soy protein-based adhesives had similar curing behaviors, but the crosslinking reaction of $B$. papyrifera leaf protein-based adhesive seems to be more complex than that of the soy protein-based adhesive. The B. papyrifera leaf proteinbased adhesive had a lower increasing trend of particle size and crystallinity than the soy-based protein adhesive, and its water resistance and bonding strength were also weaker. The plywood with BP leaf protein adhesive had dry and wet shear strengths of $0.93 \mathrm{MPa}$ and $0.59 \mathrm{MPa}$, respectively. These results are promising for future industrial production using Broussonetia papyrifera waste leaf protein as a new protein wood adhesive in the wood industry.
\end{abstract}

Keywords: Broussonetia papyrifera; leaf protein; bio-based adhesive; curing properties; bonding performance

\section{Introduction}

Research into the sustainable utilization of renewable resources is important due to increasing anthropogenic activities causing global environmental changes such as climate change and pollution. In the wood industry, great focus has been put on the production and use of ecofriendly wood adhesives based on forest and agricultural resources [1-4]. Biomass materials, such as protein, starch, tannin, and lignin are commonly employed in the manufacture of wood adhesives [5-8]. The application of protein adhesives has a long history, and they are classified as animal or plant protein adhesives based on their raw material sources $[9,10]$. Although the latter has a late start in research, it has been studied most recently. Outshining other plant protein adhesives, partial soy protein adhesive has realized industrial production, but it is mainly applied in the preparation of plywood [11-14]. Soy protein will always belong to a grain resource. The use of agricultural raw materials in the manufacturing of wood adhesives on a large scale has a detrimental impact on food security, a practice the United Nations' Food and Agriculture Organization (FAO) opposes. As a result, conducting the study of a new type of protein-based wood adhesive based on agricultural and forestry waste material would be critical in reducing reliance on soybean protein, lowering manufacturing costs, and increasing competitiveness in the market of protein-based adhesives. 
In recent years, studies about using non-crop proteins to prepare wood adhesives have begun to take shape. The study results of Lestari et al. [15] indicated that Jatropha curcas L. cake protein had considerable potential in aspects of foaming and wood adhesives. Lestari et al. [15] used Jatropha curcas L. cake protein to prepare a wood adhesive used for plywood. Roy et al. [16] have proven that spiral seaweed protein is feasible when used to prepare wood adhesives. B. papyrifera from the Moraceae family has the advantages of rapid growth, wide distribution, easy proliferation, and a short rotation. The B. papyrifera leaf is abundant in protein, with a crude protein concentration of up to $30 \%[17,18]$. B. papyrifera leaf protein was used to prepare a protein wood adhesive, and its properties were studied in this paper. This study could highlight the efficient utilization of B. papyrifera leaf forestry waste protein, as well as expand the application fields of $B$. papyrifera protein.

\section{Materials and Methods}

\subsection{Materials}

B. papyrifera powder (BP) and defatted soy flour (DS) with a protein content of $30 \%$ and 53.4\%, respectively, were from Yuxin Soybean Protein Co., Ltd. (Bingzhou, China). All of the other chemical reagents utilized in this study were analytical reagent grade. For the manufacture of plywood, a poplar veneer of thickness $1.5 \mathrm{~mm}$ and moisture content between $8 \%$ and $10 \%$ was procured from Qunyou Wood Co., Ltd., Suzhou, China. A commercial epoxy resin of E-44 was used as crosslinker for preparing the protein adhesives. For the E44, the epoxide number was $0.41-0.47$ and softening point was $12-20{ }^{\circ} \mathrm{C}$.

\subsection{Preparation of Protein-Based Adhesive}

Protein-based adhesives were manufactured using the following procedure [3]: a three-neck round-bottom flask with a thermometer, condenser, and mechanical stirrer was filled with 320 parts water. The protein powder was then added in 80 parts to the swiftly stirring solution. Then, 21.3 parts of $30 \%$ sodium hydroxide solution were introduced after the slurry was heated to $45^{\circ} \mathrm{C}$. After $30 \mathrm{~min}$ of stirring, 20 parts of a $40 \%$ urea solution was introduced and stirred for another $20 \mathrm{~min}$. In an ice bath, the slurry was cooled to room temperature. Protein-based adhesive with a $24 \pm 1 \%$ protein content was obtained. Before the preparation of three-layer plywood, B. papyrifera leaf or soy protein-based adhesives were thoroughly combined with E44 epoxy resin. The $\mathrm{pH}$ value was 9-10 for all adhesives.

\subsection{Plywood Production with Protein-Based Adhesives and the Shearing Strength Test}

Three-layer plywood $(400 \mathrm{~mm} \times 400 \mathrm{~mm} \times 4 \mathrm{~mm})$ was produced using proteinbased adhesives. Veneers with double-sided adhesive loading of $300 \mathrm{~g} / \mathrm{m}^{2}$ were used to prepare plywood and were allowed to rest at room temperature for $15 \mathrm{~min}$ to $20 \mathrm{~min}$. The plywood samples were obtained by pressing the assembled veneers under $1.0 \mathrm{MPa}$ at $160^{\circ} \mathrm{C}$ for $6 \mathrm{~min}$ in an XLB-type single-layer hot press from Shanghai Rubber Machinery Plant (Shanghai, China). The plywood was conditioned in the laboratory for 1 day at $20 \pm 2{ }^{\circ} \mathrm{C}$ and relative humidity of $65 \pm 5 \%$ before cutting into shear specimens of $100 \mathrm{~mm} \times 25 \mathrm{~mm}$. The wet shear strength of the plywood was tested using the China National Standard GB/T 9846.3 [19]. Before testing, specimens were submerged in water for $3 \mathrm{~h}$ at $63{ }^{\circ} \mathrm{C}$ and afterward exposed to ambient conditions for $10 \mathrm{~min}$. The shear strength of the plywood specimens was tested using a WDS-50 KN mechanical testing machine (Shenzhen Sansi technology Co., Ltd., Shenzhen, China). The dry and wet shear strengths were calculated using the average results of 8 to 10 specimens.

\subsection{Fourier Transform Infrared Spectroscopy (FT-IR)}

A pill was prepared by thoroughly mixing $0.001 \mathrm{~g}$ of BP or DS protein powder with $1 \mathrm{~g} \mathrm{KBr}$. A Varian 1000 infrared spectrophotometer (Varian Inc., Palo Alto, CA, USA) was used to examine the pill with a resolution of $4 \mathrm{~cm}^{-1}$ in the range of $400 \mathrm{~cm}^{-1}$ to $4000 \mathrm{~cm}^{-1}$ using 32 scans. 


\subsection{Differential Scanning Calorimetry (DSC)}

Curing degree calculation: The curing peak on the DSC curve was integrated and plotted with curing time and integral area as the $\mathrm{X}$ - and $\mathrm{Y}$-coordinates, respectively, to obtain the curing degree curve chart of the protein adhesive at various heating rates.

Kissinger equation [20] for calculating apparent activation energy, reaction order, and reaction frequency factor is shown in Equation (1):

$$
-\ln \left(\beta / T_{P}^{2}\right)=E_{a} / R T_{P}-\ln A R / E_{a}
$$

where $\beta$ is the heating rate $\left(\mathrm{K} \cdot \mathrm{min}^{-1}\right), T_{p}$ is the peak curing temperature $(\mathrm{K}), E$ is the apparent activation energy $\left(\mathrm{J} \cdot \mathrm{mol}^{-1}\right), A$ is the pre-exponential factor $\left(\mathrm{s}^{-1}\right)$, and $R$ is the general gas constant $\left(8.314 \mathrm{~J} \cdot \mathrm{min}^{-1} \cdot \mathrm{K}^{-1}\right)$.

The Kissinger equation expresses the relationships of curing apparent activation energy with heating rate and peak temperature on the thermal analysis curve as $\frac{d \ln \left(\beta / T_{p}{ }^{2}\right)}{d\left(T_{p}-1\right)}=-\frac{E}{R}$.

A straight line was plotted using $\ln \left(\beta / T_{p}{ }^{2}\right)$ vs. $1 / T_{p}$ at various heating rates $(5,10$, 15 and $20 \mathrm{~K} / \mathrm{min}$ ), and the line slope was employed to compute the apparent activation energy $E$ of the curing reaction using Equation (2):

$$
E_{\mathrm{a}}=-K R
$$

\subsection{Contact Angle}

A clean poplar veneer was coated with a certain amount of protein-based adhesive. The microscope lens and camera (JC2000A) static drop contact angle measuring instrument (Shanghai Zhongchen Company, Shanghai, China) was used to capture a picture of a droplet. The photo was taken $1 \mathrm{~s}$ after the droplet dropped on the wood surface and the contact angle was obtained.

\subsection{Particle Size of Adhesive}

A $1 \mathrm{~g}$ sample of the protein adhesive was added to $60 \mathrm{~g}$ distilled water, and the insoluble substances were removed by centrifugation. Particle size was measured on a Zetasizer Nanoparticle size instrument (Malvern Instruments, Malvern, UK).

\subsection{X-ray Diffraction (XRD)}

An XRD (Hitachi, Ltd., Tokyo, Japan) with $\mathrm{Cu} \mathrm{K} \alpha$ radiation $(\mathrm{Cu} \mathrm{K} \alpha, \lambda=1.5406 \AA$ ) at a scanning speed of $6^{\circ} / \mathrm{min}$ and a temperature range of 5 to $80^{\circ} \mathrm{C}$ was used to determine the crystalline structures of the adhesives.

\section{Results and Discussion}

\subsection{FT-IR Analysis}

Spherical proteins and linear proteins are two types of protein molecules; the former can easily create special crosslinked network structures, hence spherical protein-based adhesives exhibit a high bonding performance [21,22]. Figure 1 shows the FT-IR spectra of BP leaf and DS proteins. Most natural proteins have spherical protein structures, and soy protein is typically a spherical protein [23]. Figure 1 shows that an asymmetric stretching vibration absorption peak of methylene $-\mathrm{CH}_{2}$ appeared near $2926 \mathrm{~cm}^{-1}$, near $1648 \mathrm{~cm}^{-1}$ was an amide I band $-\mathrm{C}=\mathrm{O}$ stretching vibration absorption peak, near $1550 \mathrm{~cm}^{-1}$ was an in-plane flexural vibration absorption peak of amide II band-N-H, near $1244 \mathrm{~cm}^{-1}$ was a C-N stretching vibration peak of amide III bands [24-26], near $1402 \mathrm{~cm}^{-1}$ was a symmetric flexural vibration peak of -C-H bond, and at $1050 \mathrm{~cm}^{-1}$ were stretching vibration peaks of $\mathrm{C}-\mathrm{O}$ and $\mathrm{C}-\mathrm{O}-\mathrm{C}$. Several $-\mathrm{NH}_{2}$ and $-\mathrm{COOH}$ groups were found inside the protein, according to the FT-IR data. The FT-IR spectrograms of BP leaf protein and soy were almost the same, which indicated that BP leaf protein also belonged to the spherical protein group. 


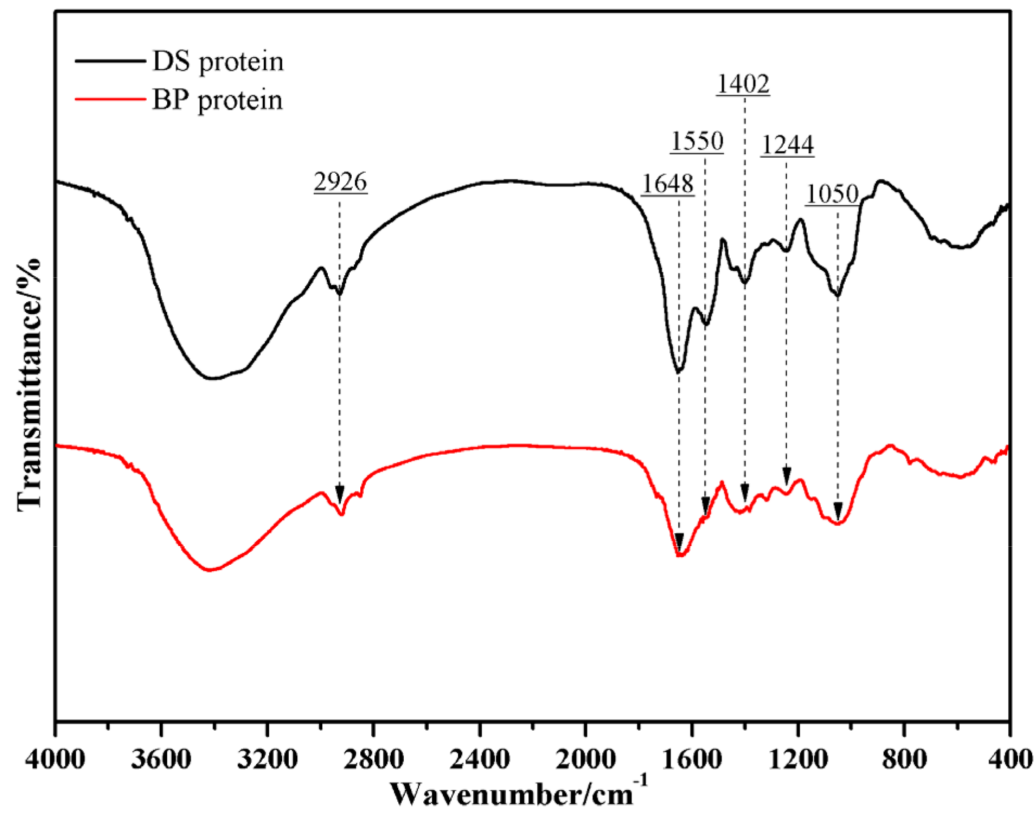

Figure 1. FT-IR spectra of BP protein and DS protein.

Degrading modification is a crucial step for the preparation of protein adhesives. In an alkaline solution, spherical protein molecules can be decomposed and loosened, exposing active groups and generating active sites for later crosslinking modification while increasing the possibility of forming intermolecular bonding during the adhesive curing process. Studies indicate that a specific secondary structure must be retained to ensure that soy protein adhesive has high cohesion strength $[27,28]$. Therefore, the degradation process not only needs to ensure that protein active groups should be effectively exposed to have high reactivity but also needs to ensure that the protein has good mobility and the major structure of the protein macromolecule will not be excessively damaged after treatment at high cohesion strength and with strong operating testing.

\subsection{DSC Analysis}

Figure 2 shows the DSC curves of BP leaf and DS protein adhesives at various heating rates. The two protein adhesives present similar curing features on the DSC curves with single exothermic peaks. The initial curing temperature $\left(T_{i}\right)$, peak temperature $\left(T_{p}\right)$, and termination temperature $\left(T_{f}\right)$ all increased correspondingly as the heating rates increased, and the curing temperature range was widened, reducing curing time. The heat generated within unit time was largely due to the heating rate increase, resulting in a high temperature differential, as well as the exothermic peak of the curing process moving to a higher temperature. The curing temperatures of the protein-based adhesives increased with the heating rate, however, the change in the BP protein adhesive was less than the DS protein adhesive as the heating rate had a minimal effect on the BP leaf protein adhesive's curing temperature.

Curing reaction degree is an important method for measuring the curing and crosslinking reactions [29]. According to Figure 3, the times needed for the curing reaction of BP and DS protein adhesives were 20,11.5, 8 and $6 \mathrm{~min}$ at heating rates of 5, 10, 15 and 20 ${ }^{\circ} \mathrm{C} / \mathrm{min}$, respectively, which indicated that the time required to obtain the same degree of curing decreased as the heating rate increased, or that the crosslinking reaction accelerated. At the heating rates of 5,10 and $15{ }^{\circ} \mathrm{C} / \mathrm{min}$, the cross-linking reaction degree of the $\mathrm{BP}$ protein adhesive was slightly less than that of DS protein adhesive. The cross-linking reaction degree of the $\mathrm{BP}$ protein adhesive was clearly greater than the DS protein adhesive at the heating rate of $20^{\circ} \mathrm{C} / \mathrm{min}$. The changing trend of crosslinking reaction degrees of the two protein adhesives at varied heating rates was related to their protein reactivity. 

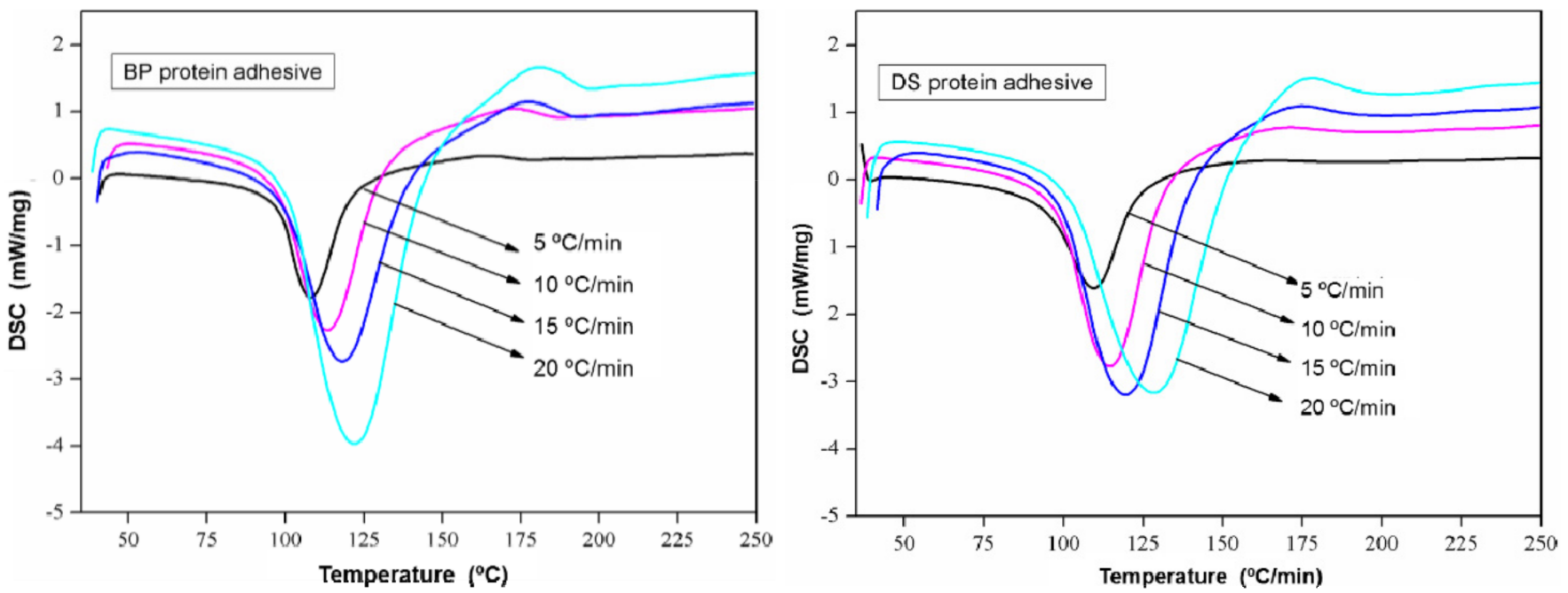

Figure 2. DSC curves at different heating rates of BP and DS protein adhesives.
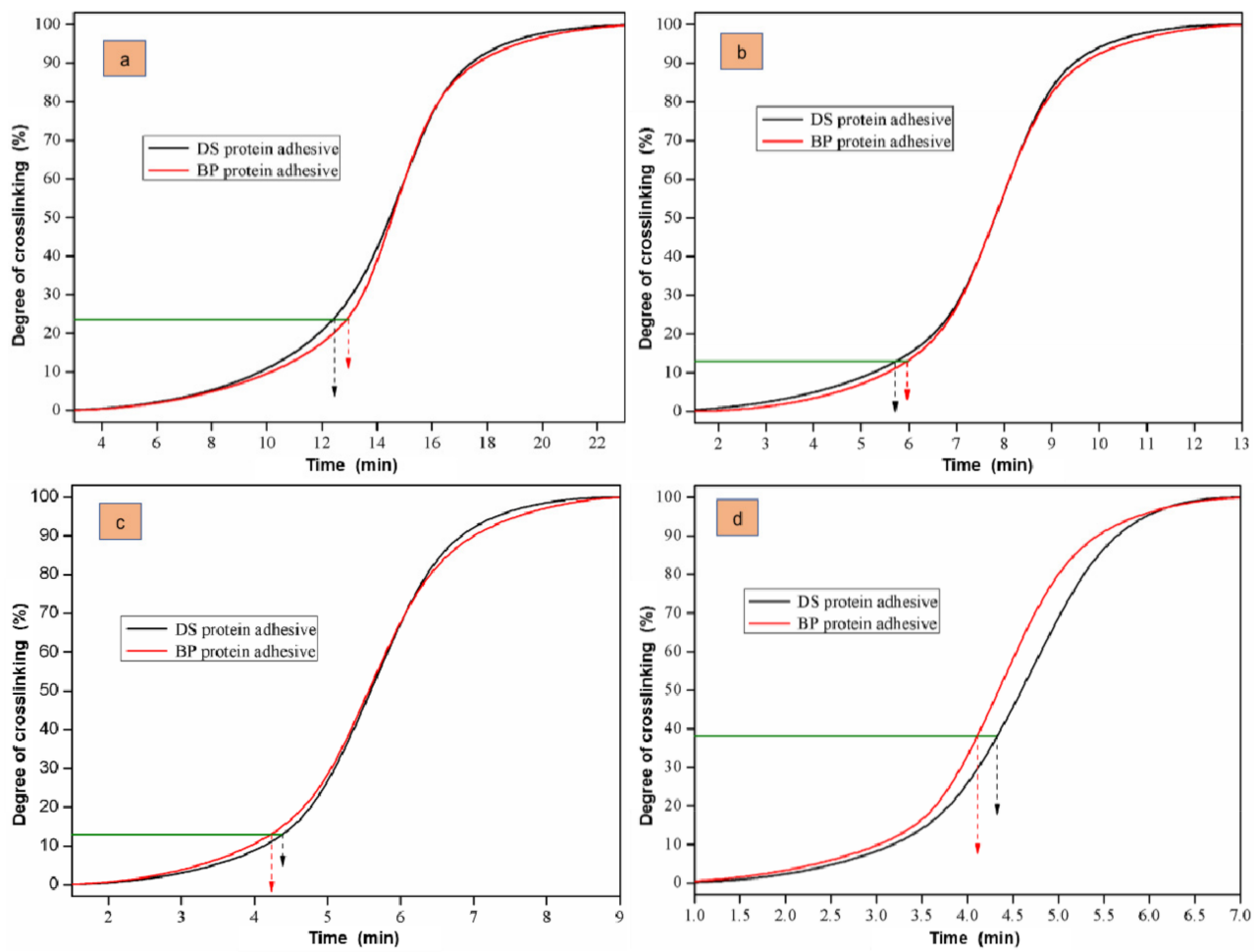

Figure 3. Crosslinking degrees of $\mathrm{BP}$ and DS protein adhesives at different heating rates: $(\mathbf{a}) 5^{\circ} \mathrm{C} / \mathrm{min}$, (b) $10{ }^{\circ} \mathrm{C} / \mathrm{min}$, (c) $15^{\circ} \mathrm{C} / \mathrm{min}$, and (d) $20^{\circ} \mathrm{C} / \mathrm{min}$.

Apparent activation energy $E_{a}$, which includes apparent activation energies of two elementary reactions and complex reactions, embodies the difficulty level of the crosslinking reaction degree of this system. The $E_{a}$ of the crosslinking reactions of BP leaf and DS protein adhesives were calculated based on DSC results in reference to the Kissinger equation [20], which were 115.41 and $84.26 \mathrm{~kJ} / \mathrm{mol}$, respectively (Table 1 ). This indicates that it was more difficult for the BP leaf protein adhesive to experience a crosslinking reaction than the DS protein adhesive. 
Table 1. DSC result parameters.

\begin{tabular}{cccccc}
\hline Adhesives & $\begin{array}{c}\text { Heating Rate } \\
\left({ }^{\circ} \mathbf{C} / \mathbf{m i n}\right)\end{array}$ & $\boldsymbol{T}_{\boldsymbol{i}}\left({ }^{\circ} \mathbf{C}\right)$ & $\boldsymbol{T}_{\boldsymbol{p}}\left({ }^{\circ} \mathbf{C}\right)$ & $\boldsymbol{T}_{f}\left({ }^{\circ} \mathbf{C}\right)$ & $\boldsymbol{E}_{\boldsymbol{a}}(\mathbf{k J} / \mathbf{m o l})$ \\
\hline \multirow{3}{*}{ BP protein adhesive } & 5 & 97.2 & 108.1 & 121.0 & \\
& 10 & 96.9 & 113.5 & 131.2 & 115.41 \\
& 15 & 99.2 & 118.3 & 138.7 & \\
DS protein adhesive & 20 & 100.1 & 122.3 & 144.1 & \\
& 10 & 94.1 & 109.6 & 124.1 & \\
& 15 & 97.3 & 114.5 & 132.1 & \\
\hline
\end{tabular}

\subsection{Contact Angle Analysis}

Figure 4 shows the contact angles of the BP leaf protein adhesive and the DS protein adhesive. The images in Figure 4 show that the contact angle of the un-crosslinked BP leaf protein was small, $17.3^{\circ}$, and it increased to $27.8^{\circ}$ after crosslinking, an improvement of $60.7 \%$. The contact angle of the DS protein increased from $19.0^{\circ}$ to $42.3^{\circ}$, an improvement of $122.6 \%$. Before crosslinking, the contact angles of both protein adhesives were very small, due to a great number of polar groups being generated in the post-degraded protein, which had strong compatibility with the hydroxyl groups in wood cellulose so that the contact angle was small $[30,31]$. The contact angles of both protein adhesives were clearly enlarged after crosslinking, which indicated that the wettability of protein adhesives after crosslinking for wood became poor, because the crosslinking agent reacted with the degraded protein, and as a result, the quantity of polar groups, such as amino acids, was reduced. The increase of the contact angle of the BP leaf protein adhesive was less than the DS protein adhesive, which further certified that the reactivity of the BP leaf protein was inferior to that of soy protein.

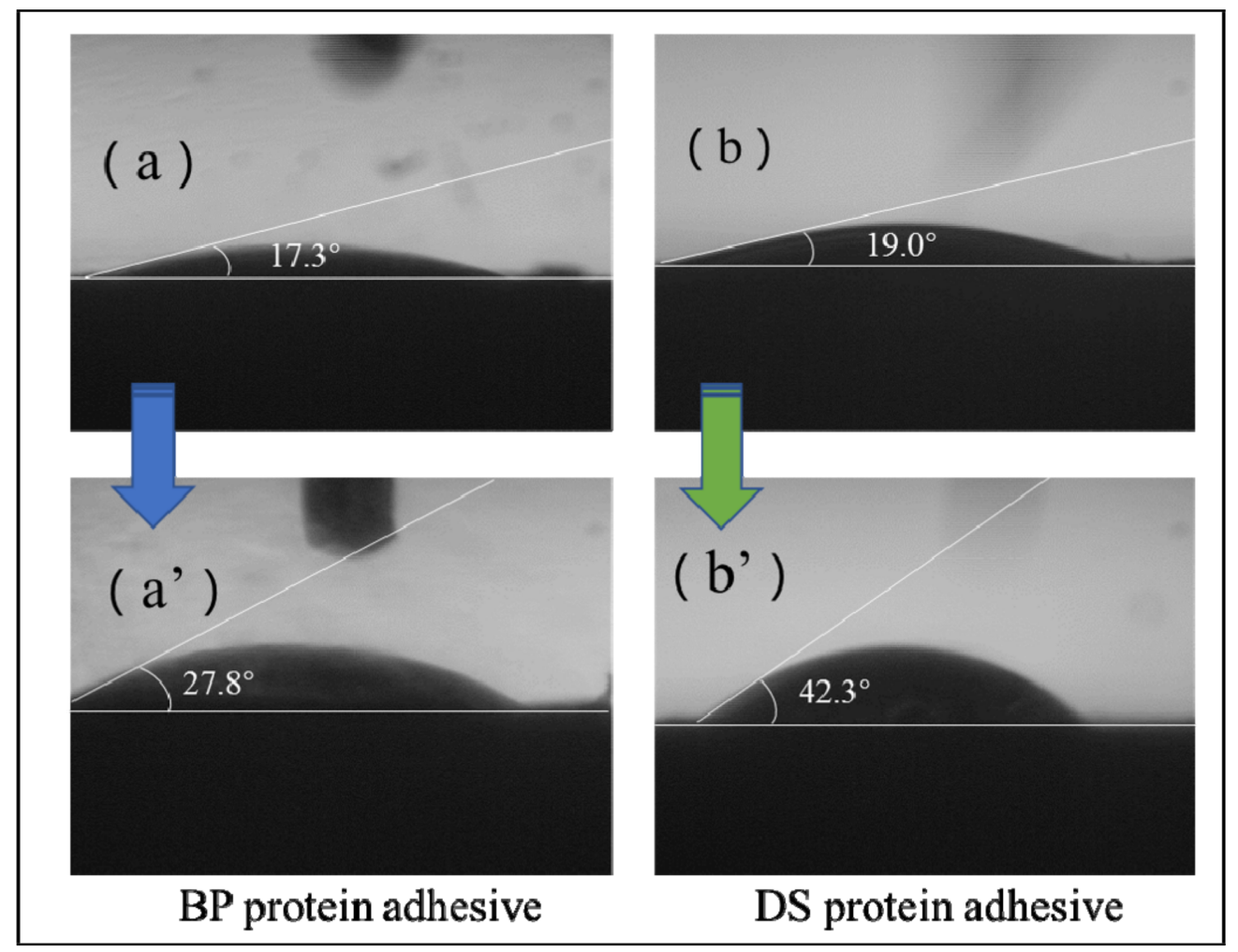

Figure 4. Contact angles of BP protein $\left(\mathbf{a}, \mathbf{a}^{\prime}\right)$ and DS protein $\left(\mathbf{b}, \mathbf{b}^{\prime}\right)$ adhesive with or without crosslinker. 
The contact angles of the BP protein adhesive and the DS protein adhesive were $27.8^{\circ}$ and $42.3^{\circ}$, respectively, both of them were smaller than $90^{\circ}$, which indicated that contact angles of both protein adhesives were enlarged after crosslinking, but they still kept strong wettability with wood. In addition, an epoxy-type crosslinker was used in this study. Residual epoxy groups in the hot-pressing process can experience chemical reactions with hydroxyls such as lignin and cellulose, and the influence of formed chemical bonds on bonding strength was greater than that on wettability. Therefore, the bonding performance of protein adhesive after crosslinking will not become poor as the wettability degrades.

\subsection{Particle Size Analysis}

Figure 5 show particle size graphs of the BP leaf protein adhesive and the DS protein adhesive. The peaks of the particle sizes of the BP leaf protein and the DS protein before crosslinking were $452.2 \mathrm{~nm}$ and $463.7 \mathrm{~nm}$, respectively, and the peaks after crosslinking became $889.2 \mathrm{~nm}$ and $1419 \mathrm{~nm}$, respectively. The peaks of the particle sizes between the two adhesives before modification were not large, but they clearly increased after modification, and thus certified that molecular chains of the BP leaf protein and the DS protein were opened and extended with the help of $\mathrm{NaOH}$, the crosslinker reacted with exposed polar groups, and as a result, molecular chains became long and particle size became large [32-36]. After crosslinking, the peaks of the particle sizes of the BP leaf protein adhesive were smaller than the DS protein adhesive, indicating that the BP leaf protein had a lower reactivity than the DS protein.
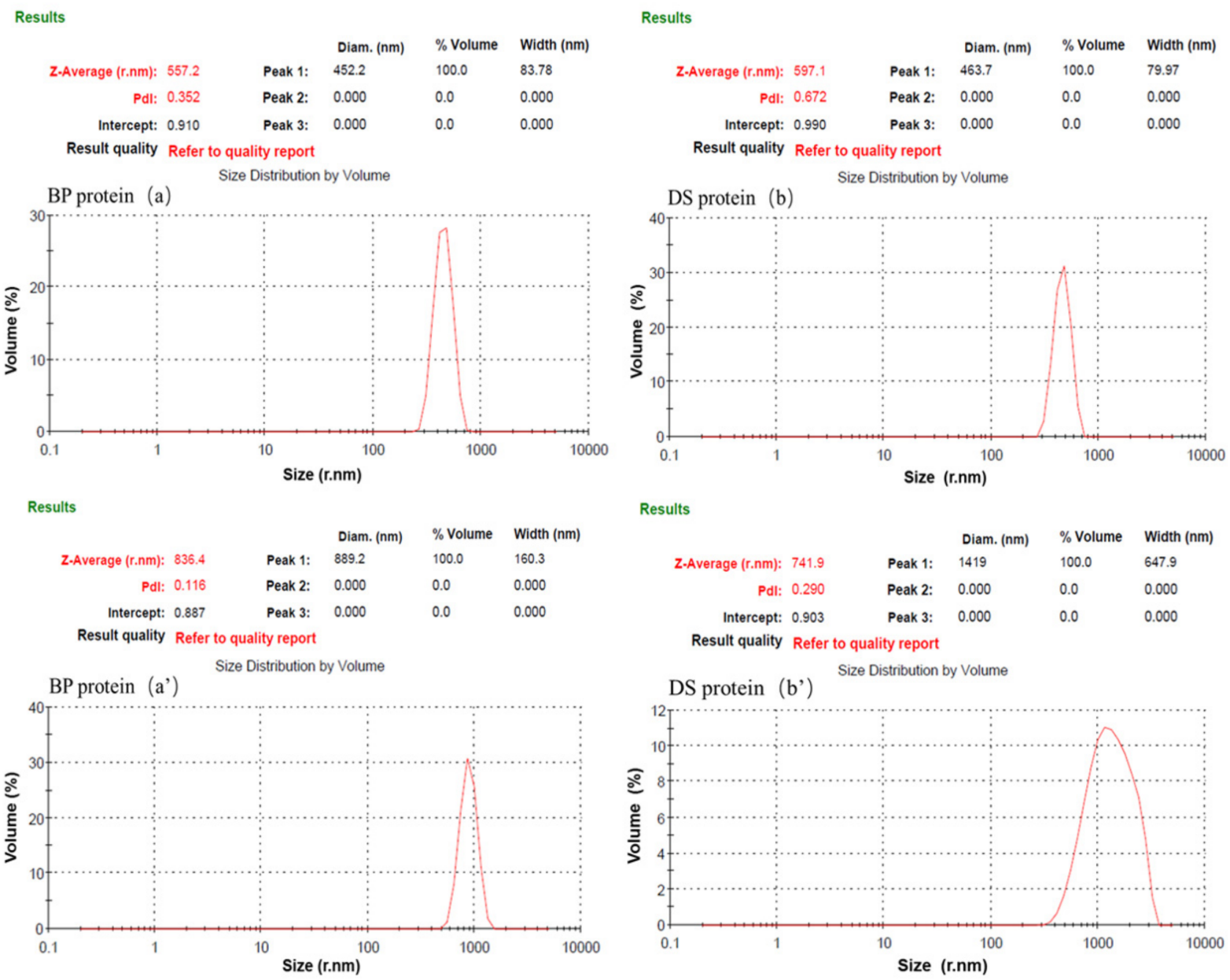

Figure 5. Premodification and postmodification of BP $\left(\mathbf{a}, \mathbf{a}^{\prime}\right)$ and DS protein adhesives $\left(\mathbf{b}, \mathbf{b}^{\prime}\right)$. 


\subsection{XRD Analysis}

After the protein adhesives reacted with the crosslinker, the degree of crystallinity increased, as well as the cohesion strength and crosslinking density of the adhesives, which finally contributed to an improvement in the water resistance and bonding strength of the adhesives. The XRD curves of the BP leaf and DS protein adhesives are shown in Figure 6. Urea and protein have a crystalline structure; however, their reaction could cause the crystallinity to be lost partially or completely, resulting in a decrease in crystallinity and the formation of a totally different three-dimensional crosslinked network structure. According to Figure 6, the degree of crystallinity of the BP leaf protein adhesive was lower compared to the DS protein adhesive. The protein reacted with the crosslinker, increasing the hydrogen-bond interaction and acting force between the crosslinker and protein, and thus the adhesive's degree of crystallinity. The BP protein reactivity and its crystallinity improvement were lower compared to the DS protein.

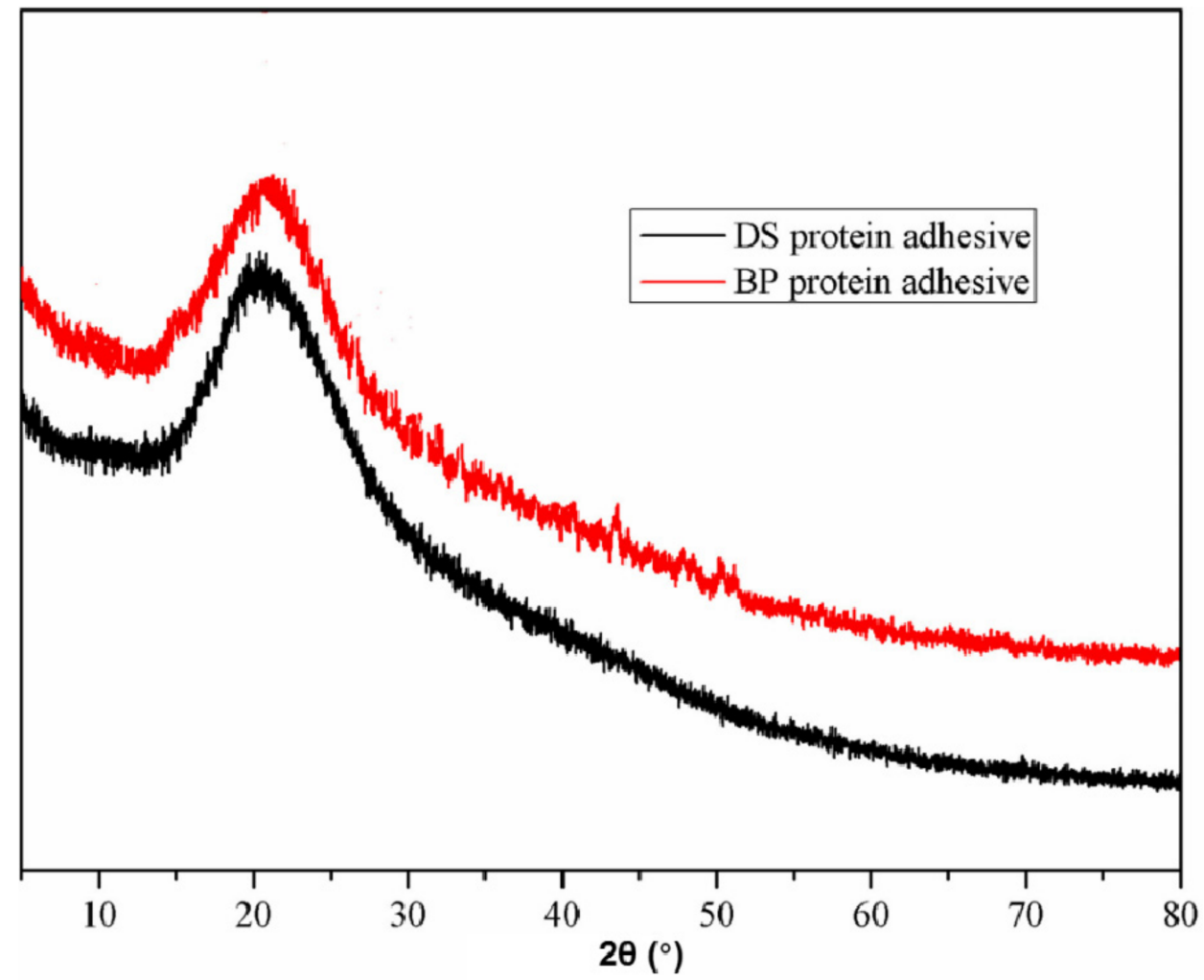

Figure 6. XRD spectrum of BP and DS protein adhesives.

\subsection{Shearing Strength}

Figure 7 shows the results of the bonding performance of the BP leaf and soy protein adhesives. The plywood with the BP leaf and soy protein adhesives had dry shear strengths of 0.83 and $1.56 \mathrm{MPa}$, and wet shear strengths of 0.59 and $1.13 \mathrm{MPa}$, respectively. The cohesion strength and crosslinking density of the adhesives have a strong effect on their water resistance and bonding strength. Under a certain amount of crosslinker, the most likely factor that influenced the crosslinking density of adhesive was protein activity after degradation. Therefore, the poor activity of the BP leaf protein resulted in poor bonding performance. Nevertheless, this study lays a foundation for the development of novel protein-based adhesives by increasing raw material availability. 


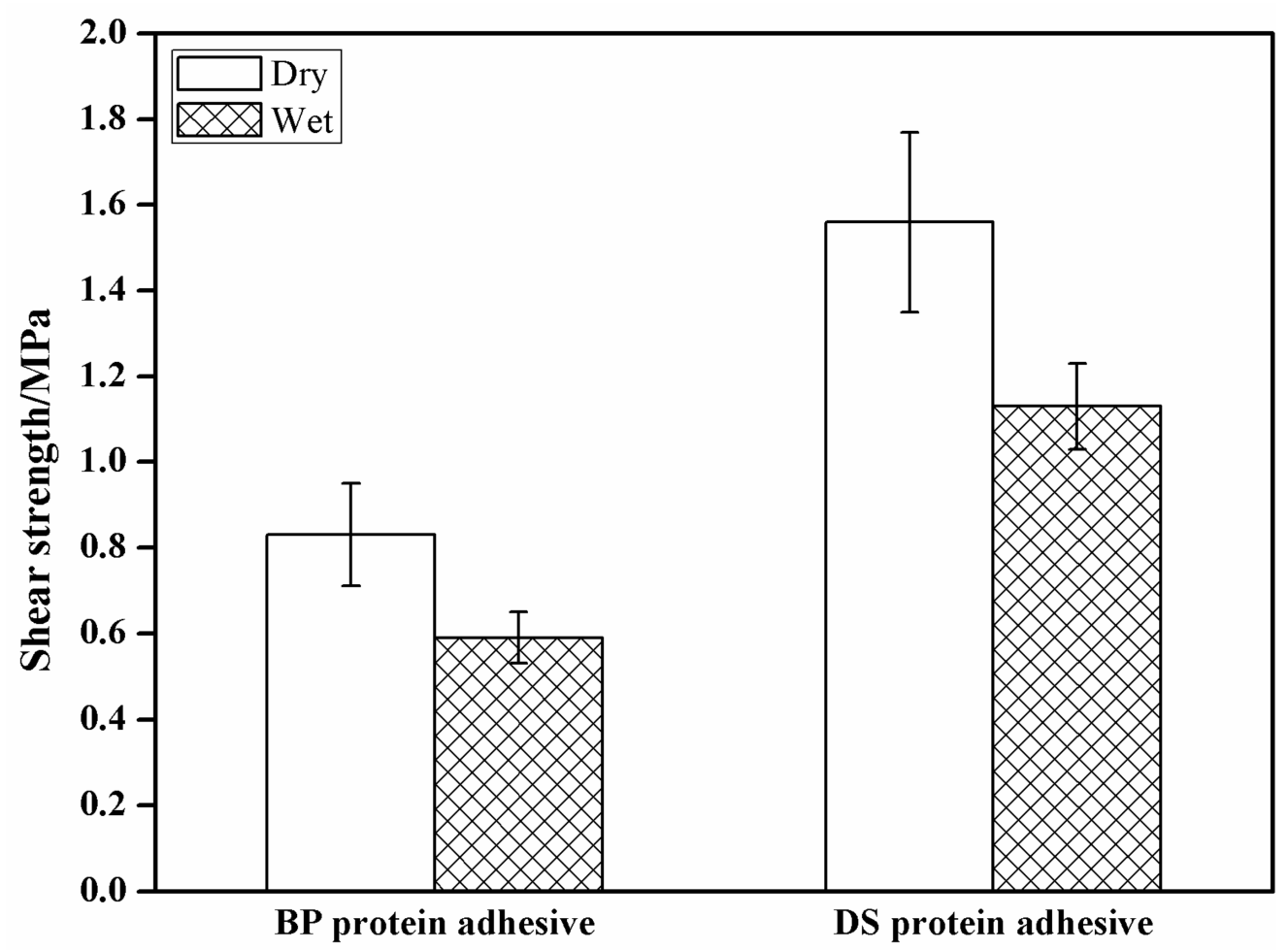

Figure 7. Bonding properties of BP protein adhesive and DS protein adhesive. Note: all dry wood failures were over $50 \%$ and those of BP protein adhesive were low. All wet wood failures were less than $30 \%$ and those of BP protein adhesive were low.

\section{Conclusions}

In this study, we found that both B. papyrifera leaf protein and soybean protein were spherical proteins that could easily form three-dimensional crosslinked network structures with the potential for protein adhesive preparation. B. papyrifera leaf and soy protein adhesives had comparable curing behaviors, and the heating rate influence on the curing temperature of B. papyrifera leaf protein adhesive was less compared to soy protein adhesive at the lower rates. The crosslinking activation energies of B. papyrifera leaf protein adhesive and soy protein adhesive were 115.41 and $84.26 \mathrm{~kJ} / \mathrm{mol}$, respectively, indicating that the crosslinking reactions of $B$. papyrifera leaf protein adhesive seem more complex than soy protein adhesive. After crosslinking, the contact angles of both protein adhesives were remarkably enlarged, their wettability with wood deteriorated, and the contact angle of B. papyrifera leaf protein adhesive improved less compared to soy protein adhesive. The B. papyrifera leaf protein adhesive showed good shearing strength and water resistance, which lays a solid foundation for raw material expansion for new protein-based adhesives.

Author Contributions: CrediT authorship contribution statement: Conceptualization, C.L., X.Y.; methodology, Z.W., B.Z.; validation, C.L., Y.T. and Y.W.; formal analysis, C.L. and X.Y.; investigation, C.L. and H.T.; resources, C.L., B.Z. and Z.W.; data curation, C.L., X.Y.; writing-original draft preparation, C.L., X.Y.; writing-review and editing, C.L. and B.Z.; visualization, C.L. and Y.T.; supervision, B.Z., Z.W. and X.Y.; project administration, B.Z. and Z.W.; funding acquisition, C.L. and $X . Y$. All authors have read and agreed to the published version of the manuscript.

Funding: This research was funded by the National Natural Science Foundation of China (32160348), the Key scientific research projects of institutions of high education in Henan (21A220001), the Key Research and Development Foundation of Henan (212102110182), the Science-Technology Support Foundation of Guizhou Province of China (ZK [2021]162 and [2019]2325), the Special Fund for Young Talents in Henan Agricultural University (30500928), and the Henan Province Natural Science Foundation (202300410210). 


\section{Data Availability Statement: Not applicable.}

Conflicts of Interest: The authors declare no conflict of interest.

\section{References}

1. Pizzi, A. Recent developments in eco-efficient bio-based adhesives for wood bonding: Opportunities and issues. J. Adhes. Sci. Technol. 2006, 20, 829-846. [CrossRef]

2. Pizzi, A.; Tondi, G.; Pasch, H.; Celzard, A. Matrix-assisted laser desorption/ionization time-of-flight structure determination of complex thermoset networks: Polyflavonoid tannin-furanic rigid foams. J. Appl. Polym. Sci. 2008, 110, 1451-1456. [CrossRef]

3. Wu, Y.; Li, X.; Zuo, Y.; Li, X.; Qin, Y.; Zhang, X. Research status on the utilization of forest and agricultural biomass in inorganic wood-based panel. J. For. Eng. 2016, 1, 8-15. [CrossRef]

4. Xi, X.; Wu, Z.; Pizzi, A.; Gerardin, C.; Lei, H.; Zhang, B.; Du, G. Non-isocyanate polyurethane adhesive from sucrose used for particleboard. Wood Sci. Technol. 2019, 53, 393-405. [CrossRef]

5. Xu, F.; Dong, Y.; Zhang, W.; Zhang, S.; Li, L.; Li, J. Preparation of cross-linked soy protein isolate-based environmentally-friendly films enhanced by PTGE and PAM. Ind. Crops Prod. 2015, 67, 373-380. [CrossRef]

6. Zhao, X.; Peng, L.; Wang, H.; Wang, Y.; Zhang, H. Environment-friendly urea-oxidized starch adhesive with zero formaldehydeemission. Carbohydr. Polymer. 2018, 181, 1112-1118. [CrossRef]

7. Ghahri, S.; Pizzi, A. Improving soy-based adhesives for wood particleboard by tannins addition. Wood Sci. Technol. 2018, 52, 261-279. [CrossRef]

8. Stücker, A.; Schütt, F.; Saake, B.; Lehnen, R. Lignins from enzymatic hydrolysis and alkaline extraction of steam refined poplar wood: Utilization in lignin-phenol-formaldehyde resins. Ind. Crops Prod. 2016, 85, 300-308. [CrossRef]

9. Bacigalupe, A.; Escobar, M.M. Soy protein adhesives for particleboard production-A review. J. Polym. Environ. 2021, 29, 2033-2045. [CrossRef]

10. Lamaming, S.Z.; Lamaming, J.; Rawi, N.F.M.; Hashim, R.; Kassim, M.H.M.; Hussin, M.H.; Bustami, Y.; Sulaiman, O.; Amini, M.H.M.; Hiziroglu, S. Improvements and limitation of soy protein-based adhesive: A review. Polym. Eng. Sci. 2021, 61, 2393-2405. [CrossRef]

11. Qi, G.; Sun, X.S. Soy protein adhesive blends with synthetic latex on wood veneer. J. Am. Oil Chem. Soc. 2010, 88, 271-281. [CrossRef]

12. Qi, G.; Li, N.; Wang, D.; Sun, X.S. Physicochemical properties of soy protein adhesives obtained by in situ sodium bisulfite modification during acid precipitation. J. Am. Oil Chem. Soc. 2012, 89, 301-312. [CrossRef]

13. Wu, Z.; Du, G.; Lei, H.; Xi, X.; Cao, M.; Guo, X. Preparation of eco-friendly urea-formaldehyde resin by urea-formaldehyde precondensate and soy protein. J. For. Eng. 2016, 1, 31-36. [CrossRef]

14. $\mathrm{Wu}, \mathrm{Z} . ; \mathrm{Xi}, \mathrm{X} . ;$ Lei, H.; Du, G. Soy-based adhesive cross-linked by phenol-formaldehyde-glutaraldehyde. Polymers 2017, 9, 169. [CrossRef] [PubMed]

15. Lestari, D.; Mulder, W.; Sanders, J. Jatropha seed protein functional properties for technical applications. Biochem. Eng. J. 2011, 53, 297-304. [CrossRef]

16. Roy, J.; Sun, L.; Ji, L. Microalgal proteins: A new source of raw material for production of plywood adhesive. J. Appl. Phycol. 2014, 26, 1415-1422. [CrossRef]

17. Kwak, W.J.; Moon, T.C.; Lin, C.X.; Rhyn, H.G.; Jung, H.; Lee, E.; Kwon, D.Y.; Son, K.H.; Kim, H.P.; Kang, S.S.; et al. Papyriflavonol A from Broussonetia papyrifera inhibits the passive cutaneous anaphylaxis reaction and has a secretory phospholipase $\mathrm{A}_{2-}$ inhibitory activity. Biol. Pharm. Bull. 2003, 26, 299-302. [CrossRef]

18. Ryu, H.W.; Lee, B.W.; Curtis-Long, M.J.; Jung, S.; Ryu, Y.B.; Lee, W.S.; Park, K.H. Polyphenols from Broussonetia papyrifera displaying potent alpha-glucosidase inhibition. J. Agric. Food Chem. 2010, 58, 202-208. [CrossRef]

19. GB/T 9846.3. Test Methods of Evaluating the Properties of Wood-Based Panels; Standardization Administration of China: Beijing, China, 2004.

20. Kissinger, H.E. Reaction kinetics in differential thermal analysis. Anal. Chem. 1957, 29, 1702-1706. [CrossRef]

21. Wu, Z.; Lei, H.; Du, G. Disruption of soy-based adhesive treated by $\mathrm{Ca}(\mathrm{OH})_{2}$ and $\mathrm{NaOH}$. J. Adhes. Sci. Technol. 2013, $27,2226-2232$. [CrossRef]

22. Wu, Z.; Lei, H.; Cao, M.; Xi, X.; Liang, J.; Du, G. Soy-based adhesive cross-linked by melamine-glyoxal and epoxy resin. J. Adhes. Sci. Technol. 2016, 30, 2120-2129. [CrossRef]

23. Tian, H.; Guo, G.; Fu, X.; Yao, Y.; Yuan, L.; Xiang, A. Fabrication, properties and applications of soy-protein-based materials: A review. Int. J. Biol. Macromol. 2018, 120, 475-490. [CrossRef]

24. Zeng, Y.; Xu, P.; Yang, W.; Chu, H.; Wang, W.; Dong, W.; Chen, M.; Bai, H.; Ma, P. Soy protein-based adhesive with superior bonding strength and water resistance by designing densely crosslinking networks. Eur. Polym. J. 2021, 142, 110128. [CrossRef]

25. Yue, L.; Shi, R.; Yi, Z.; Shi, S.Q.; Gao, Q.; Li, J. A high-performance soybean meal-based plywood adhesive prepared via an ultrasonic process and using significantly lower amounts of chemical additives. J. Clean. Prod. 2020, 274, 123017. [CrossRef]

26. Gu, W.; Liu, X.; Ye, Q.; Gao, Q.; Gong, S.; Li, J.; Shi, S.Q. Bio-inspired co-deposition strategy of aramid fibers to improve performance of soy protein isolate-based adhesive. Ind. Crops Prod. 2020, 150, 112424. [CrossRef] 
27. Li, H.; Li, C.; Gao, Q.; Zhang, S.; Li, J. Properties of soybean-flour-based adhesives enhanced by attapulgite and glycerol polyglycidyl ether. Ind. Crops Prod. 2014, 59, 35-40. [CrossRef]

28. Vnučec, D.; Goršek, A.; Kutnar, A.; Mikuljan, M. Thermal modification of soy proteins in the vacuum chamber and wood adhesion. Wood Sci. Technol. 2015, 49, 225-239. [CrossRef]

29. Wu, Z.; Zhang, B.; Zhou, X.; Li, L.; Yu, L.; Liao, J.; Du, G. Influence of single/collective use of curing agents on the curing behavior and bond strength of soy protein-melamine-urea-formaldehyde (SMUF) resin for plywood assembly. Polymers 2019, 11, 1995. [CrossRef]

30. Xu, H.; Shen, Q.; Ouyang, X.; Yang, L. Wetting of soy protein adhesives modified by urea on wood surfaces. Eur. J. Wood Wood Prod. 2012, 70, 11-16. [CrossRef]

31. Wu, Z.; Xi, X.; Pizza, A.; Xia, Y.; Zhao, Q.; Lei, H.; Liang, J. Effects of Broussonetiapapyrifera leaf cutting modes on bonding performance of its protein-based adhesives. Eur. J. Wood Wood Prod. 2020, 78, 461-470. [CrossRef]

32. Zhang, Y.; Shi, R.; Xu, Y.; Chen, M.; Zhang, J.; Gao, Q.; Li, J. Developing a stable high-performance soybean meal-based adhesive using a simple high-pressure homogenization technology. J. Clean. Prod. 2020, 256, 120336. [CrossRef]

33. Liang, J.; Li, Q.; Wu, Z.; Du, G.; Li, T.; Lei, H.; Li, L. Competitive polycondensation of model compound melamine-ureaformaldehyed (MUF) resin system by ${ }^{13} \mathrm{C}$ NMR. J. Bioresour. Bioprod. 2020, 5, 60-66. [CrossRef]

34. Hao, X.; Fan, D. Preparation and characterization of epoxy-crosslinked soy protein adhesive. J. Adhes. Sci. Technol. 2018, 32, 2682-2692. [CrossRef]

35. Xia, Z.; Li, J.; Zhang, J.; Zhang, X.; Zheng, X.; Zhang, J. Processing and valorization of cellulose, lignin and lignocellulose using ionic liquids. J. Bioresour. Bioprod. 2020, 5, 79-95. [CrossRef]

36. Zhang, N.; Li, Z.; Xiao, Y.; Pang, Z.; Jia, P.; Feng, G.; Bao, C.; Zhou, Y.; Hua, L. Lignin-based Phenolic Resin Modified with Whisker Silicon and Its Application. J. Bioresour. Bioprod. 2020, 5, 67-77. [CrossRef] 